Article

\title{
Improved Sustainability of Water Supply Options in Areas with Arsenic-Impacted Groundwater
}

\author{
Edward A. McBean ${ }^{1}$, Mohammad Adnan Rajib ${ }^{2, *}$ and Md. Mujibur Rahman ${ }^{3}$
}

1 College of Physical and Engineering Science, University of Guelph, Burnaby, Guelph, ON N1G 2W1, Canada; E-Mail: emcbean@uoguelph.ca

2 School of Civil Engineering, Purdue University, West Lafayette, IN 47907, USA

3 Department of Civil Engineering, Bangladesh University of Engineering and Technology (BUET), Dhaka 1000, Bangladesh; E-Mail: mujib@ce.buet.ac.bd

* Author to whom correspondence should be addressed; E-Mail: adnanrajib@purdue.edu; Tel.: +1-765-409-4047.

Received: 14 October 2013; in revised form: 16 November 2013 / Accepted: 18 November 2013 / Published: 26 November 2013

\begin{abstract}
The supply of water for rural populations in developing countries continues to present enormous problems, particularly where there is arsenic contamination in the groundwater, as exists over significant parts of Bangladesh. In response, improvements in the sustainability of water supplies are feasible through the use of a combination of water sources wherein rainwater harvesting is employed for a portion of the year. This can potentially reduce the duration of the year during which arsenic-contaminated groundwater is utilized. As demonstrated, a rainwater cistern volume of $0.5 \mathrm{~m}^{3}$ in the Jessore district area of Bangladesh can provide rainwater for periods averaging 266 days of the year, which allows groundwater at $184 \mu \mathrm{g} / \mathrm{L}$ arsenic to be used as a water supply for the remainder of the year. This dual supply approach provides the body burden equivalent to the interim drinking water guideline of arsenic concentration of $50 \mu \mathrm{g} / \mathrm{L}$ for 365 days of the year (assuming the water consumption rate is $4 \mathrm{~L} / \mathrm{cap} /$ day for a family of five with a rainwater collection area of $15 \mathrm{~m}^{2}$ ). If the water use rate is $20 \mathrm{~L} / \mathrm{cap} / \mathrm{day}$, the same cistern can provide water for 150 days of the year; however, although this is insufficient to supply water to meet the body burden equivalent guideline of $50 \mu \mathrm{g} / \mathrm{L}$. Results are provided also for different rooftop areas, sizes of cisterns and alternative arsenic guidelines [World Health Organization (WHO) and Bangladeshi]. These findings provide useful guidelines on supply options to meet sustainability targets of water supply. However, they also demonstrate that
\end{abstract}


the use of cisterns cannot assist the meeting of the $10 \mu \mathrm{g} / \mathrm{L}$ WHO target arsenic body burden, if the arsenic contamination in the groundwater is high (e.g., at $100 \mu \mathrm{g} / \mathrm{L}$ ).

Keywords: arsenic; Bangladesh; carcinogens; contamination; climate change; groundwater; rainwater harvesting; risk assessment; water supply

\section{Introduction}

Supply of water safe for consumption to individuals is widely considered a basic human right; however, the ability to provide a safe supply of water is becoming increasingly difficult and particularly difficult for rural populations in developing countries. The challenges are intensifying in part due to the combination of escalating water demands from the increasing populations, increasing desertification and climate change [1,2]. Clearly, the challenges are enormous and will intensify with time, due to population increases and climate change.

Contaminants in the source water complicate the challenges of providing sustainable safe water supplies to rural populations in many South Asian countries. There, surface water sources are found in relative abundance during much of the year, but are highly impacted by pathogens. For example, only $13 \%$ of the sewage produced by India's 1.1 billion people is treated, and an estimated 700 million of its citizens have no access to a proper toilet [3]. As a result, downstream surface water is contaminated, causing safety limits to be exceeded. For example, at Varanasi, India, the Ganges contains 60,000 fecal coliform bacteria per 100 milliliters, one hundred and twenty times more than is considered safe for bathing. Four miles downstream, the concentration is 3000 times the safety limit [3].

In response to the widespread presence of microbial contamination in South Asia, in the early 1980 s, there were dramatic shifts away from the use of surface water, toward the use of groundwater as the preferred water supply source. However, reliance upon groundwater as a water supply source was later found to be highly problematic, due to the identification of high concentrations of naturally occurring arsenic in the groundwater.

Attempts to relocate groundwater withdrawals to avoid the highly arsenic-contaminated groundwater were found to be impossible in many locales. Illustrated in Figure 1 is a map characterizing arsenic contamination in groundwater at three different aquifer levels (where the entire southern part of the country has high arsenic contamination). Further, more than $90 \%$ of all tube wells in Samta (see Figure 1 for the location) were contaminated with arsenic exceeding the Bangladesh guideline of $50 \mu \mathrm{g} / \mathrm{L}$ for drinking water [4]. This, in turn, has resulted in renewed interest for surface water as supply sources. The severity of the problem is recognized with the awareness that arsenic concentrations in groundwater reach, for example, $550 \mu \mathrm{g} / \mathrm{L}$ or 11 times the Bangladeshi guideline (as reported in [5] using the Bangladesh Arsenic Mitigation Water Supply Project (BAMWSP) data), and hence, many locations require extensive treatment. Due to the very limited budgets of rural populations, there are no funds available to accomplish this level of treatment.

Given these findings, it is not surprising that there have been increasing governmental initiatives to return to reliance upon microbially-contaminated surface water and to decrease reliance upon groundwater $[2,6]$. However, although there are significant efforts to develop and promote the return to 
surface water supply options, there is considerable resistance from rural people, since they feel the clarity of groundwater is far superior (user perception) to surface water and there is "status" associated with having a tube well.

Figure 1. Arsenic concentration ( $\mathrm{ppb}$ ) at different depths all over Bangladesh.
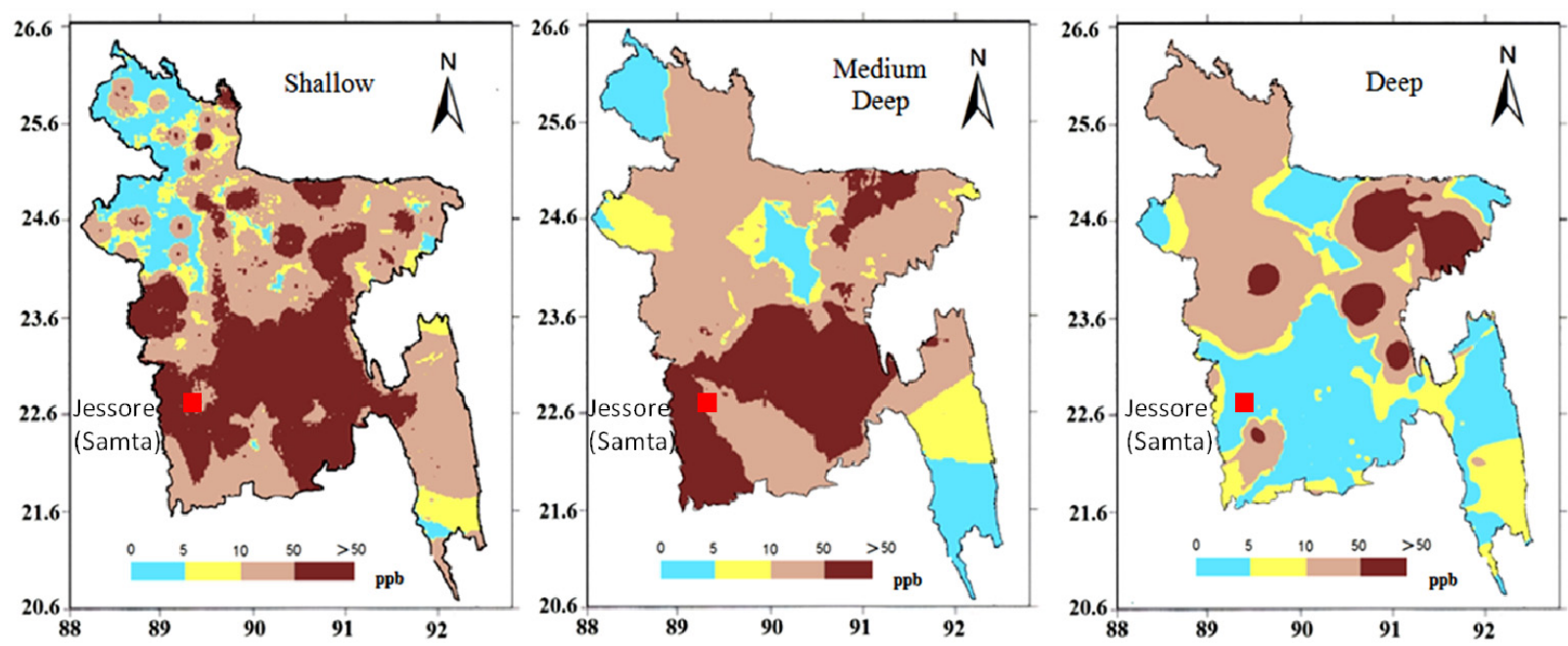

It must be acknowledged that arsenic-contaminated groundwater is a particular challenge. As will be demonstrated in the following sections, meeting the World Health Organization (WHO) water quality standard for arsenic does not attain an incremental cancer risk of one in a million, since the necessary treatment is just too challenging [2]. However, as shown herein, using risk assessment procedures that employ United States Environmental Protection Agency (U.S. EPA) guidelines, it is possible to adopt an alternative strategy relying upon a combination of water sources, which can maintain the expected cancer risk at a level equivalent in body burden to meeting the WHO interim arsenic guideline. This can be accomplished through an approach relying upon multiple water sources, namely, rainwater for a portion of the year and groundwater for the remainder of the year.

\section{Background and State of the Problem}

Concern exists with long-term consumption of drinking water containing high levels of arsenic, due to the increased risk of cancer in the skin, lungs, bladder and kidney. Some arsenic compounds, such as volatile arsine $\left(\mathrm{AsH}_{3}\right)$, are not present in food or water. Further, metallic arsenic (zero valence) is not absorbed from the stomach and, as such, does not have any adverse effect on the human body. As a result, the exposure scenarios to arsenic must be assessed, reflecting the specific forms and pathways of human exposure to arsenic.

Arsenic contamination in ground water in a significant portion of Bangladesh has been recognized as a major problem since 1993 [7]. The National Hydro-chemical Survey being conducted by the British Geological Survey (BGS) provides the most comprehensive data for arsenic concentrations in Bangladesh [8]. A total of 3534 tube wells all over Bangladesh were sampled and tested for arsenic. The collected samples characterize three different depth locations (shallow: 0 to $50 \mathrm{~m}$; medium: 50 to $120 \mathrm{~m}$; deep: more than $120 \mathrm{~m}$ ) along the geologic formation. The occurrence of arsenic in Bangladesh at three different geologic depth-ranges, as observed from the above-mentioned comprehensive water 
quality survey, is displayed in Figure 1. Severe arsenic contamination is prominent in shallow and medium well depths; concentrations exceeding $10 \mu \mathrm{g} / \mathrm{L}$ are over almost all of the country, except in the north-western region. The central and south-western parts of the country exhibit concentrations of arsenic that are even exceeding the Bangladesh standard $(50 \mu \mathrm{g} / \mathrm{L})$. Even the deep wells in the north-eastern part show considerable arsenic hazard. Although appropriate technologies have been installed in some rural areas, such as AIRPs (Arsenic-Iron Removal Plants), in many situations, user perception and acceptability of existing removal technologies, as well as maintenance of the systems are not satisfactory. Therefore, a sophisticated treatment system is neither practicable for small-scale drinking water supply in rural areas nor economically feasible.

It is noted that arsenic issues are not unique to the developing world; problems of arsenic contamination are widespread, e.g., most provinces and territories across Canada report some areas where arsenic can be detected in drinking water supplies. For example, Meranger et al. [9] reported that levels exceeded $50 \mu \mathrm{g} / \mathrm{L}$ in $33 \%-93 \%$ of wells in each of seven communities in Nova Scotia, Canada; concentrations were greater than $500 \mu \mathrm{g} / \mathrm{L}$ in $10 \%$ of the wells sampled. However, affordability and technical sophistication of treatment to meet arsenic guidelines are more achievable in developed countries.

\section{Risk Assessment Calculations for Arsenic}

To utilize risk assessment in a typical application (e.g., see [10]), reliance is normally accomplished using exposure scenarios in which the incremental risk of cancer/death exceeds one in a million (i.e., the quality of water on the basis of increasing the probability of cancer by one in a million). One in a million is referred to as "de minimus" (minimal) risk [11,12]. Hence, the guideline for a carcinogen is normally established at a level where the increased cancer risk is: "essentially negligible" when a person is exposed at that level in drinking water over a lifetime, such as 70 years [11]. This approach is generally adopted, such that one new case of cancer is instigated above the background per 100,000 people to one million people (i.e., a probability range from $10^{-5}$ to $10^{-6}$ ). To demonstrate by calculations if the arsenic concentration in water is $0.03 \mu \mathrm{g} / \mathrm{L}$ and for a daily water consumption of $2 \mathrm{~L} /$ capita/day, the daily intake, DI, of arsenic becomes:

$$
\mathrm{DI}=(0.03 \mu \mathrm{g} / \mathrm{L})(2 \mathrm{~L} / \text { day })=0.06 \mu \mathrm{g} / \text { day }
$$

The Lifetime Average Daily Dose, or LADD, is calculated as:

$$
\mathrm{LADD}=(\mathrm{DI} \times \mathrm{EF} \times \mathrm{ED}) /(365 \mathrm{AT})
$$

where, $\mathrm{EF}=$ exposure frequency; $\mathrm{ED}=$ exposure duration; $\mathrm{AT}=$ averaging time (years).

Hence, for a $70 \mathrm{~kg}$ body weight (BW) individual in a developed country, with a life expectancy of 70 years, consuming $2 \mathrm{~L}$ /day of water, the LADD is:

$$
\begin{aligned}
\operatorname{LADD}=(0.06 / 1,000 \mathrm{mg} / \text { day } \times & 365 \text { days } / \text { year } \times 70 \text { years }) /(70 \mathrm{~kg} \times 70 \text { years } \times 365 \text { days } / \text { year }) \\
& =8.57 \times 10^{-7} \mathrm{mg} / \mathrm{kg} \mathrm{BW} / \text { day }
\end{aligned}
$$

The Incremental Excess lifetime Cancer Risk, IELCR, is computed as:

$$
\mathrm{IELCR}=\mathrm{LADD} \times \mathrm{CSF}
$$


where CSF = cancer slope factor, indicating the carcinogenicity. The cancer slope factor for arsenic is $1.5 /(\mathrm{mg} / \mathrm{kg} \times$ day) [13], yielding the cumulative risk to the individual consuming the water to be:

$$
\text { IELCR }=8.57 \times 10^{-7} \times 1.5=1.28 \times 10^{-6} \text { (unitless) }
$$

In other words, the exposure risk to the individual consuming water at $0.03 \mu \mathrm{g} / \mathrm{L}$ for 70 years is "de minimus" (the risk or probability is between $10^{-5}$ and $10^{-6}$ ).

\section{Risk Assessment Calculations Using WHO and Country-Specific Guidelines for Arsenic}

The WHO lowered the Guideline Value for arsenic in drinking water from $50 \mu \mathrm{g} / \mathrm{L}$ to $10 \mu \mathrm{g} / \mathrm{L}$ in 1993 [14]. However, the interim drinking water guideline employed at this time in Bangladesh has remained at $50 \mu \mathrm{g} / \mathrm{L}$.

Given the preceding, consider the exposure risk arising from the consumption of arsenic-impacted water for a person in Bangladesh. Assuming an arsenic concentration of $50 \mu \mathrm{g} / \mathrm{L}$ in the water, over a life expectancy of 63 years for Bangladesh [15], with a consumption rate of $4 \mathrm{~L} / \mathrm{cap} / \mathrm{day}$ (due to the warm climate) and a body weight of $70 \mathrm{~kg}$, the exposure risk is calculated as:

IELCR (with an arsenic standard of $50 \mu \mathrm{g} / \mathrm{L}$ ) $=4.3 \times 10^{-3}$

The IELCR for an arsenic concentration of $50 \mu \mathrm{g} / \mathrm{L}$ is an exposure risk $4.3 \times 10^{-3} / 1.28 \times 10^{-6}$ or 3359 times as large as adopted in developed countries.

It is apparent from the above that attainment of arsenic concentrations commensurate with the "de minimus" risk approach is extremely difficult, due to the ubiquitous nature of arsenic in groundwater and the challenges of arsenic removal from water [16].

\section{Potential for Reliance upon Multiple Water Sources as a Means of Ameliorating the Cancer Risk}

While accepting the exposure risk associated with the arsenic interim guideline of $50 \mu \mathrm{g} / \mathrm{L}$, as noted above, groundwater in extensive areas of South Asia in general, and Bangladesh, in particular, exceed the arsenic guideline. When that guideline is exceeded, the approach must be either: (i) to treat the water to decrease the arsenic concentrations to $50 \mu \mathrm{g} / \mathrm{L}$ or less (which is challenging) [16]; or (ii) to rely upon the arsenic-impacted groundwater for only a portion of the year and use another source of water for the remainder of the year. The procedure by which (ii) can be accomplished is examined below.

For villagers to benefit from having a safe water supply, the supply system has to be selected based on the geological condition of their area. Rainwater harvesting is a possible option for portions of the year, since there is no entrained arsenic. It is noted that consideration herein is not given to dug wells and/or pond sand filters, only tube wells (after McBean et al. [2]; Rajib et al. [17]).

Rainwater is naturally free of pathogens, arsenic and even minerals, which are normally present in groundwater, such as salts of calcium and magnesium, iron, manganese, fluorides, nitrates, etc. However, problems with rainwater harvesting include: the microbial pollution, which may arise due to bird droppings on the rooftop from which the rainwater is harvested, and contamination within the storage container itself (e.g., occurring due to the vessel being used to retrieve water for consumption from the cistern), as well as the cost of water storage. More than eighty percent of the system cost for a rainwater harvesting system is incurred by the construction of the storage reservoir (e.g., $500 \mathrm{~L}, 1 \mathrm{~m}^{3}$, 
$\left.2 \mathrm{~m}^{3}, 2.5 \mathrm{~m}^{3}, 3.2 \mathrm{~m}^{3}\right)$. Given that the period of rainfall is typically intense for approximately three months (e.g., in Jessore, Bangladesh, 71 percent of the rainfall during the period 1995-2004 occurred in three months, June through August), the potential to employ a storage container to provide water for a number of months of the year represents an opportunity. It is noted that while it may be difficult to rely on rainwater harvesting, since the water contained in the cistern may deteriorate in quality, this dimension is ignored in the analyses that follow.

To assess the potential contribution towards the water needs that can be serviced from rainwater harvesting, a water balance simulation model was employed to determine for ten years (1995-2004) of daily rainfall in the Jessore/Samta area of Bangladesh, the duration of time a rainwater cistern could produce the daily water needs. Using the model, a series of investigations are described to assess the merits of different sizes of cisterns, rooftop areas and the feasibility of meeting different arsenic guidelines (WHO and Bangladeshi). To begin, consider, first, the following scenario for assessment:

(i) The 10-year daily rainfall record for the period 1995 to 2004 for the Jessore/Samta region was employed in the analyses;

(ii) Assume that the capture zone for the roof rainwater harvesting system is $5 \mathrm{~m}$ by $3 \mathrm{~m}$;

(iii) Assume that the water consumption from the cistern is $4 \mathrm{~L} / \mathrm{cap} /$ day for a family of five. This magnitude assumes the water from the cistern is used just for direct consumption.

The duration of time that cisterns of varying size can supply the water for the family is depicted in Figure 2. Relevant findings from Figure 2 include:

(i) There is relatively little merit in having a cistern of a size larger than $1 \mathrm{~m}^{3}$, and even that size is not much more effective than a cistern volume of $0.5 \mathrm{~m}^{3}$;

(ii) Some years are obviously wetter than others, and hence, the utility of the cistern varies from a low in 1999 to a high in 1998 ;

(iii) Figure 3 characterizes the average length of time that cisterns of different sizes are effective at supplying the water for the family. For example, changing the cistern from 0.5 to $1 \mathrm{~m}^{3}$ would provide water for the family, on average, for $(289-266)=23$ days more per year (see Tables 1 and 2);

(iv) Using the cistern water for the maximum duration feasible for the purposes of drinking water supply and since the groundwater in Jessore is $100 \mu \mathrm{g} / \mathrm{L}$ [5], none of the cistern sizes are able to meet the arsenic body burden for the WHO standard of $10 \mu \mathrm{g} / \mathrm{L}$ (see line 2 in Tables 1 and 2; it is not feasible to reach the arsenic body burden equivalent to the WHO guideline). However, for the Bangladeshi standard of $50 \mu \mathrm{g} / \mathrm{L}$, any of the cistern sizes are sufficient, and for the $4 \mathrm{~L} / \mathrm{cap} /$ day demand, for 0.5 and $1 \mathrm{~m}^{3}$ cistern volumes, to keep the arsenic body burden equivalent to the Bangladeshi arsenic guideline.

As a further assessment of sensitivity to input parameters, Figures 4 and 5 indicate the durations of times that cisterns of varying size can supply $20 \mathrm{~L} / \mathrm{cap} /$ day for a family of five, for a rooftop collection area of $15 \mathrm{~m}^{2}$ and $7.5 \mathrm{~m}^{2}$, respectively. The $20 \mathrm{~L} /$ cap/day consumption rate assumes the use of the water from the cistern for a greater array of functions, where now the $0.5-\mathrm{m}^{3}$ cistern with a $7.5-\mathrm{m}^{2}$ rooftop can only supply water for 96 days (see line 4 of Table 1) on average (decreased from the previous $4 \mathrm{~L} /$ cap/day, for 242 days), a substantial decrease in the utility of the cistern as an alternate water 
supply. Table 1 lists, for a cistern of $0.5 \mathrm{~m}^{3}$, the number of days and the maximum allowable arsenic concentration that would be feasible (and meet the body burden for alternative arsenic guidelines, WHO or Bangladeshi). Table 2 lists the comparable information for a cistern of $1 \mathrm{~m}^{3}$ and demonstrates that for a $1-\mathrm{m}^{3}$ cistern volume, the number of days that the $1 \mathrm{~m}^{3}$ cistern can supply water represents an increase from 149 to 171 days for the higher water consumption rate, or an increase of 22 days.

It is also important to note that even a $3.2-\mathrm{m}^{3}$ cistern volume is not sufficient to allow the WHO $10 \mu \mathrm{g} / \mathrm{L}$ body burden of arsenic to be reached, if the groundwater concentration is $100 \mu \mathrm{g} / \mathrm{L}$ arsenic. A $3.2-\mathrm{m}^{3}$ cistern volume would only attain a $10 \mu \mathrm{g} / \mathrm{L}$ arsenic body burden if the groundwater arsenic concentration is $53 \mu \mathrm{g} / \mathrm{L}$ or less.

Figure 2. Durations of time that cisterns of varying size can supply $4 \mathrm{~L} /$ cap/day water during the period of 1995-2004 in the Jessore area, Bangladesh, with a 15- $\mathrm{m}^{2}$ rooftop.

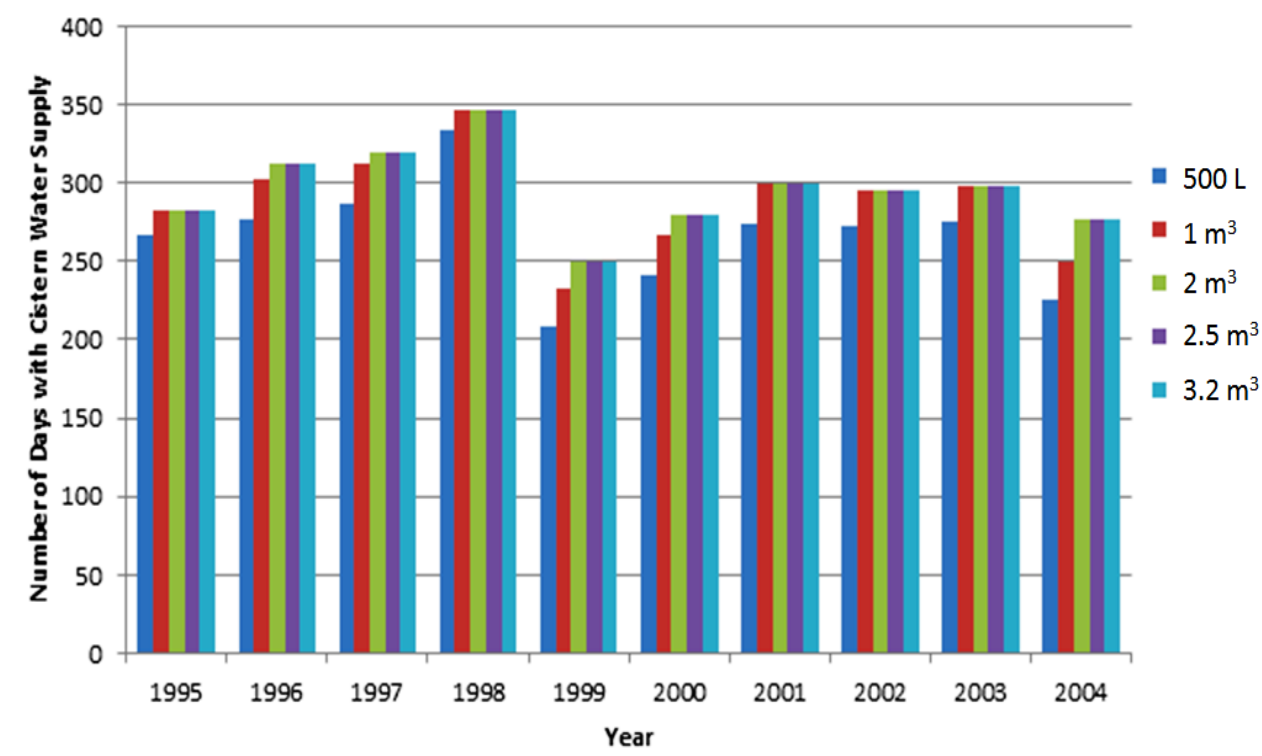

Figure 3. Comparison of the average length of time that cisterns of varying size can provide $4 \mathrm{~L} /$ cap/day for a family of five in the Jessore area, Bangladesh, with $15-\mathrm{m}^{2}$ rooftop.

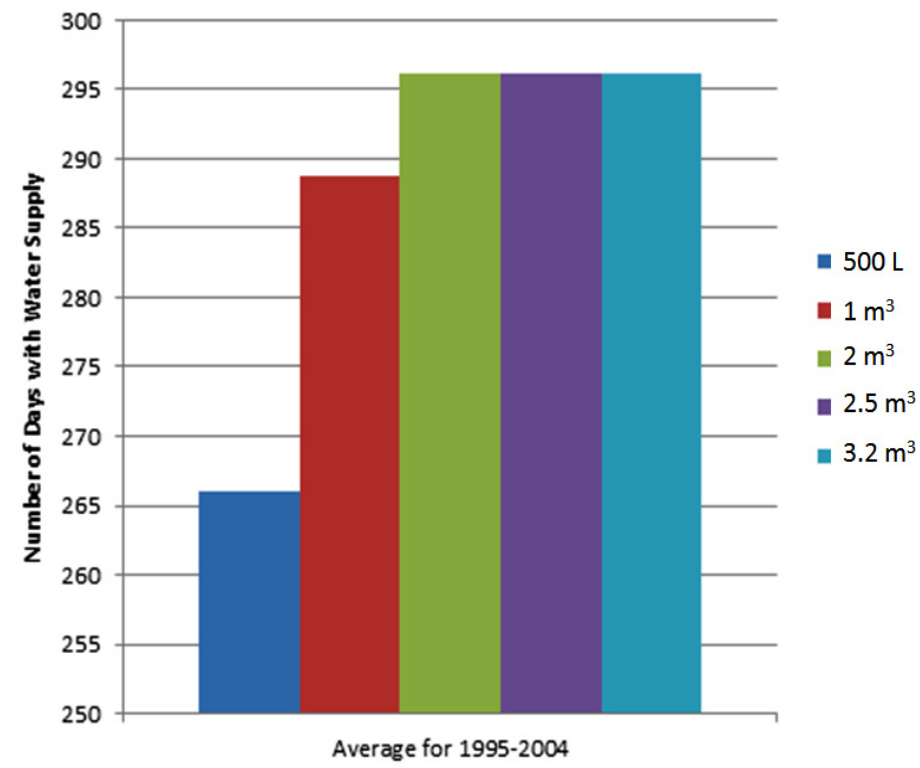


Table 1. Number of days and the maximum allowable arsenic concentration in groundwater for alternative water demands and rooftop areas (cistern volume: $0.5 \mathrm{~m}^{3}$ ). WHO, World Health Organization.

\begin{tabular}{ccccc}
\hline $\begin{array}{c}\text { Water } \\
\text { demand } \\
(\mathbf{L} / \mathbf{c a p} / \mathbf{d a y})\end{array}$ & $\begin{array}{c}\text { Rooftop } \\
\text { area }\left(\mathbf{m}^{\mathbf{2}}\right)\end{array}$ & $\begin{array}{c}\text { Number of days/year } \\
\text { meeting water demand }\end{array}$ & $\begin{array}{c}\text { Maximum arsenic } \\
\text { in groundwater } \\
\text { (for WHO 10 } \boldsymbol{\mu g} / \mathbf{L})\end{array}$ & $\begin{array}{c}\text { Maximum arsenic in } \\
\text { groundwater (for } \\
\text { Bangladeshi 50 } \mathbf{\mu g} / \mathbf{L})\end{array}$ \\
\hline 4 & 15 & 266 & 37 & 184 \\
4 & 7.5 & 242 & 30 & 149 \\
20 & 15 & 149 & 17 & 85 \\
20 & 7.5 & 96 & 14 & 68 \\
\hline
\end{tabular}

Table 2. Number of days and the maximum allowable arsenic concentration in groundwater for alternative water demands and rooftop areas (cistern volume: $1 \mathrm{~m}^{3}$ ).

\begin{tabular}{ccccc}
\hline $\begin{array}{c}\text { Water } \\
\text { demand } \\
(\mathbf{L} / \mathbf{c a p} / \mathbf{d a y})\end{array}$ & $\begin{array}{c}\text { Rooftop } \\
\text { area }\left(\mathbf{m}^{\mathbf{2}}\right)\end{array}$ & $\begin{array}{c}\text { Number of days/year } \\
\text { meeting water demand }\end{array}$ & $\begin{array}{c}\text { Maximum arsenic } \\
\text { in groundwater } \\
\text { (for WHO } \mathbf{~ 1 0} \boldsymbol{\mu} \mathbf{g} / \mathbf{L})\end{array}$ & $\begin{array}{c}\text { Maximum arsenic in } \\
\text { groundwater (for } \\
\text { Bangladeshi 50 } \mathbf{\mu g} / \mathbf{L})\end{array}$ \\
\hline 4 & 15 & 289 & 48 & 240 \\
4 & 7.5 & 266 & 37 & 185 \\
20 & 15 & 171 & 19 & 94 \\
20 & 7.5 & 107 & 14 & 71 \\
\hline
\end{tabular}

Figure 4. Durations of time that cisterns of varying size can supply $20 \mathrm{~L} /$ cap/day water during the period 1995-2004 in the Jessore area, Bangladesh, for a 15- $\mathrm{m}^{2}$ rooftop.

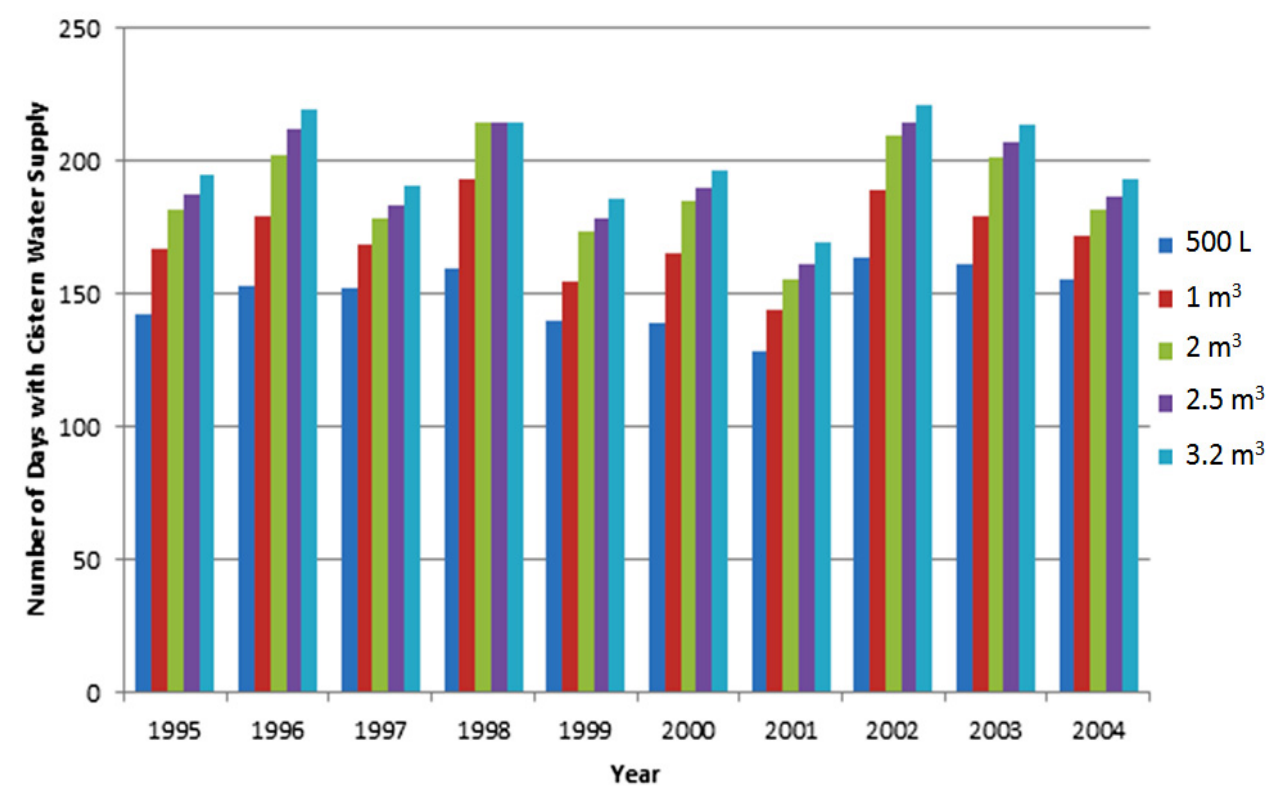

Another important finding that demonstrates that the size of the cistern is important, but not crucial, is that the average numbers of days with spillage, for different sizes of cistern, are listed in Table 3 (assuming $4 \mathrm{~L} / \mathrm{cap} /$ day as the water consumption rate). These findings can assist decision-makers in any suggested purchase of cisterns to control the arsenic body burden. If the water demands are low on a per capita basis, there is little merit in the larger cistern, but where water demands are higher, larger 
cisterns do provide additional periods where the rural populations can rely on the rainwater. Further, the use of cisterns cannot assist the meeting of the $10 \mu \mathrm{g} / \mathrm{L}$ WHO target arsenic body burden, if the arsenic contamination in the groundwater is high (e.g., $100 \mu \mathrm{g} / \mathrm{L}$ ).

Figure 5. Durations of time that cisterns of varying size can supply $20 \mathrm{~L} /$ cap/day during the period 1995-2004 in the Jessore area, Bangladesh, for a 7.5- $\mathrm{m}^{2}$ rooftop.

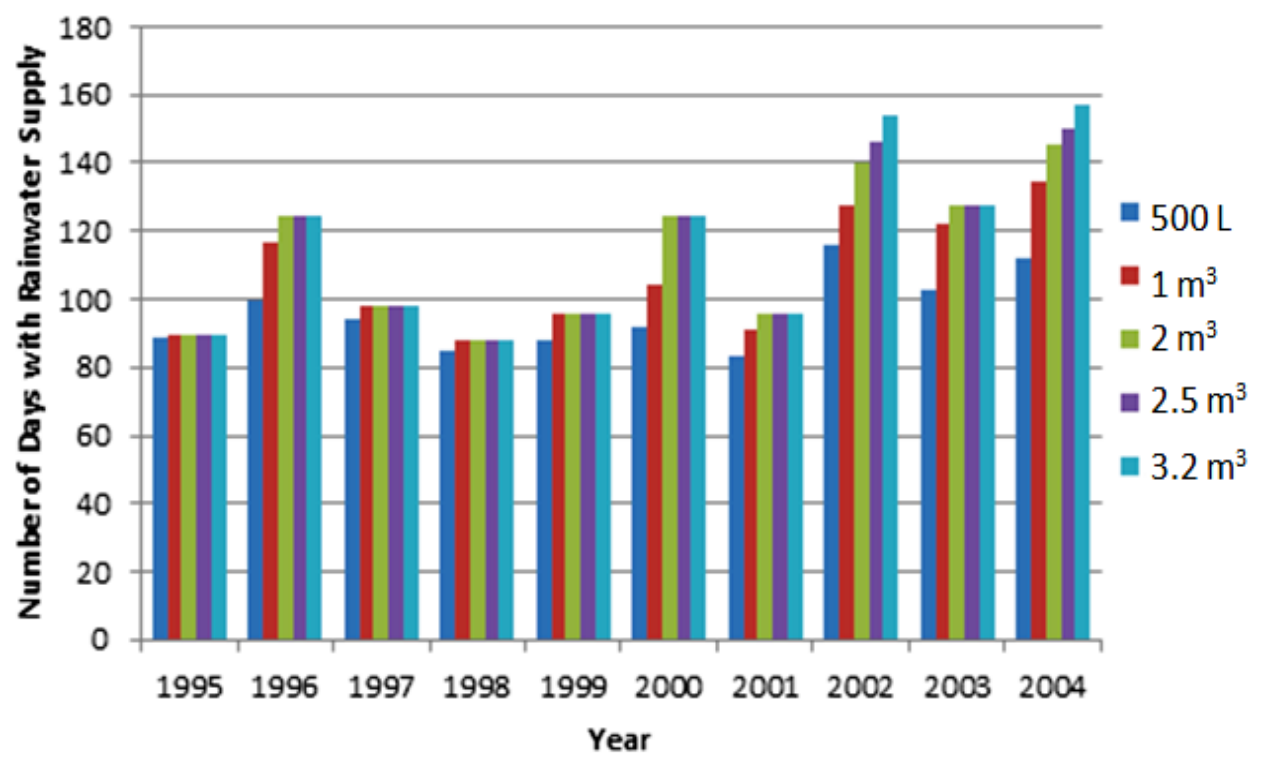

Table 3. Number of days of spillage (during period 1995-2004) with alternative rooftop sizes (based on $4 \mathrm{~L} /$ cap/day and five family members).

\begin{tabular}{|c|c|c|}
\hline Cistern size $\left(\mathrm{m}^{3}\right)$ & $\begin{array}{l}\text { Average No. of days with spillage } \\
(1995-2004) \text { with } 15-\mathrm{m}^{2} \text { rooftop }\end{array}$ & $\begin{array}{l}\text { Average No. of days with spillage } \\
(1995-2004) \text { with } 7.5 \mathrm{~m}^{2} \text {-rooftop }\end{array}$ \\
\hline 0.5 & 75 & 56 \\
\hline 1 & 73 & 51 \\
\hline 2 & 69 & 44 \\
\hline 2.5 & 66 & 40 \\
\hline 3.2 & 64 & 36 \\
\hline
\end{tabular}

\section{Conclusions}

Arsenic contamination is a widespread and challenging issue for water supply to rural populations in many developing countries. U.S. EPA risk assessment procedures have demonstrated that even adhering to the water quality guidelines represents a risk to consumers of water that is 3359 times higher than generally utilized within developed countries (assuming water consumed at the rate of $4 \mathrm{~L} / \mathrm{cap} /$ day). A possible option to alleviate the challenges of decreasing the body-burden of arsenic from groundwater is to employ rainwater harvesting in combination with groundwater as two sources of water supply. This mixed-source water option provides a more sustainable strategy by which the potential exists to use the combination of rainwater and groundwater, where the groundwater exceeds the guidelines for arsenic, while retaining the same overall risk of cancer, due to arsenic exposure. In the example developed, rainwater storage is sufficient to provide the water supply, on average, from 184 to 240 days in the year with cistern volumes of $0.5 \mathrm{~m}^{3}$ and $1.0 \mathrm{~m}^{3}$, for low water consumption rates. 
However, if the arsenic contamination in groundwater is high (e.g., $100 \mu \mathrm{g} / \mathrm{L}$ ), cistern volumes less than $1.0 \mathrm{~m}^{3}$ cannot supply sufficient water to a family of five to meet the WHO guideline for arsenic body burden.

\section{Acknowledgments}

The assistance of Ryan Brennan, Katy Falk, Zoey Zimmer and Asif Khan Ankur in the development of the water balance model, as well as the arsenic contamination map is appreciated. Research funding from the Canada Research Chairs program of Canada is also gratefully acknowledged.

\section{Conflicts of Interest}

The authors declare no conflict of interest.

\section{References}

1. McBean, E.A. Global Climate Change, Its Projected Impacts on Water Resources. In Proceedings of Plenary Presentation, 3rd Iran Water Resources Management Conference, Tabriz, Iran, 21-24 October 2008.

2. McBean, E.A., Rahman, M.M.; Rajib, M.A. Assessment of Climate Change Impacts on Small Drinking Water Systems in Bangladesh. In Proceedings of the International Conference on Climate Change Impacts and Adaptation Strategies for Bangladesh, International Training Network-Bangladesh University of Engineering and Technology, Dhaka, Bangladesh, 18-20 February 2009; pp. 53-60.

3. Economist Creaking, Groaning, Infrastructure Is India's Biggest Handicap. Available online: http://www.economist.com/node/12749787?story_id=12749787 (accessed on 15 November 2013).

4. Asia Arsenic Network, Japan International Cooperation Agency. Water Quality and Follow-up Survey on Arsenic Contamination of Dugwells in Sharsha. Upazila.; Arsenic Mitigation Project, Report 2; Asia Arsenic Network and Japan International Cooperation Agency: Dhaka, Bangladesh, 2004.

5. Ahmed, K.M.; Ravenscroft, P. Review of Data on the Status of Arsenic Pollution and Arsenic Mitigation. In Bangladesh for Revision of the Implementation Plan for Arsenic Mitigation 2009; WSP-WB World Bank Dhaka Office: Agargaon, Dhaka, Bangladesh, 2009.

6. Asia Arsenic Network, Japan International Co-operation Agency. Pond Sand Filter, Arsenic Mitigation Project, Report 3; Asia Arsenic Network, Japan International Cooperation Agency: Dhaka, Bangladesh, 2004.

7. Kabir, A.; Howard, G. Sustainability of arsenic mitigation in Bangladesh: Results of a functionality survey. Int. J. Environ. Health Res. 2007, 17, 207-218.

8. British Geological Survey. Groundwater Studies of Arsenic Contamination in Bangladesh. In Final Report, Department of Public Health Engineering; Department of International Development, British Geological Survey: Dhaka, Bangladesh, 2000.

9. Meranger, J.C.; Subramanian, K.; McCurdy, S. Arsenic in Nova Scotia Groundwater. Sci. Total Environ. 1984, 39, 49-55. 
10. McBean, E.A.; Rovers, F.A. Statistical Procedures for Analysis of Environmental Monitoring Data and Risk Assessment; Prentice-Hall Publishing Co. Inc.: Englewood Cliffs, NJ, USA, 1998.

11. United States Environmental Protection Agency. Integrated Risk Information System (IRIS). National Center for Environmental Assessment: Washington, DC, USA, 1996.

12. United States Environmental Protection Agency. National Primary Drinking Water Regulations: Arsenic and Clarifications to Compliance and New Source Contaminants Monitoring; United States Environmental Protection Agency: Washington, DC, USA, 2001.

13. United States Environmental Protection Agency. Proposed Guidelines for Carcinogenic Risk Assessment. Fed. Regist. 1996, 61, 17960-18011.

14. World Health Organization. Guidelines for Drinking Water Quality; World Health Organization: Geneva, Switzerland, 2006.

15. Airninja Life Expectancy in Bangladesh. Available online: http://www.airninja.com/worldfacts/ countries/Bangladesh (accessed on 10 October 2011).

16. Health Canada. Guidelines for Canadian Drinking Water Quality: Guideline Technical Document-Arsenic. Available online: http://www.hc-sc.gc.ca/ewh-semt/alt_formats/hecssesc/pdf/pubs/water-eau/arsenic/arsenic-eng.pdf (accessed on 15 November 2013).

17. Rajib, M.A.; Rahman, M.M.; Islam, S.; McBean, E.A. Analyzing the Future State of Monthly Precipitation Pattern in Bangladesh from Multi-Model Projections Using both GCM and RCM. In Proceedings of the World Environmental \& Water Resources Congress, American Society of Civil Engineers, Palm Springs, CA, USA, 22-26 May 2011; pp. 3843-3851.

(C) 2013 by the authors; licensee MDPI, Basel, Switzerland. This article is an open access article distributed under the terms and conditions of the Creative Commons Attribution license (http://creativecommons.org/licenses/by/3.0/). 